\title{
Aikuiskoulutuksen ja yhteiskunnan välisestä vuorovaikutuksesta ja sen kehittämisestä
}

\section{Yhteiskunnallisen muutoksen vaatimukset aikuiskasvatukselle}

Yhteiskunnallinen muutos niin Suomessa kuin muuallakin on ollut nopea. Ammattirakenteen ja työtehtävien luonne on merkittävästi muuttunut ja edelleen muuttumassa.
Ennusteiden mukaan useat entiset ammatit ovat kokonaan katoamassa, vain palvelualoilla toimivien suhteellinen määrä lisääntyy. Vielä puoli vuosisataa sitten syntyperä määräsi yksilön ammatin ja yhteiskunnallisen aseman koko eliniäksi. Nykyään ei sen sijaan kukaan voi ammattiin valmistuessaan tietää miltä alalta hän eläkkeelle siirtyy.
Myös ihmisen asema yhteiskunnan jäsenenä on muuttumassa. Häneltä odotetaan suurempaa panosta yhteisiin elinympäristönsä asioihin. Yhteiskunnan jäsenenä toimiessaan hän tarvitsee yhä lisääntyviä valmiuksia. Aikuiskoulutuksen johtoryhmä hahmotti yhteiskunnallista muutosta seuraavasti (1980): 
',Etenkin taloudellisen kasvun hidastuminen ja epävarmuus sekä teknologian kehitys tekevät välttämättömäksi arvioida uudelleen elämän perusarvoja ja sitä maailmankuvaa, jonka pohjalta tulevaisuuden suunnitelmat tehdään. Yhteiskuntasuunnittelussa pyritään estämään vieraantumista aiheuttavien tekijöiden synty. Ekologisiin kysymyksiin kiinnitetään aikaisempaa huomattavasti enemmän huomiota. Teknologian yhteiskunnallisia vaikutuksia on alettu selvittää tavoitteena niiden saaminen säädettyyn hallintaan"'

Aikuiskoulutuksen kannalta keskeinen kysymys on, kuinka yleinen suhtautuminen tulevaisuuteen, työhön, koulutukseen ja vapaa-aikaan kehittyy. Elämän perusasenne, suhtautuminen tulevaisuuteen ratkaisee aikuisten osallistumisen koulutukseen. Ammatillisen aikuiskoulutuksen kannalta on keskeistä työn yleinen arvostaminen; halutaanko ammattiuralla edetä ja koetaanko koulutus työllisyyden edistäjänä ja uralla etenemisen välineenä. Suhtautuminen vapaa-aikaan on toinen olennainen koulutukseen osallistumiseen vaikuttava tekijä; koetaanko itsensä kehittäminen tärkeäksi vai onko olennaisempaa käyttää vapaa-aika vain lepoon ja virkistykseen.

Aikuiskoulutuksen johtoryhmä näkee tärkeäksi koulutusjärjestelmän kehittämisen siten, että se luo kansalaisille todelliset edellytykset hallita yhteiskunnallisia muutoksia ja antaa niille haluamansa muoto ja suunta sekä sopeutua muutoksiin niiltä osin kuin ne ovat välttämättömiä $\mathrm{ja} /$ tai tavoiteltavia. Aikuiskoulutusjärjestelmältä tämä edellyttää joustavuutta ja mukautumiskykyä, laaja-alaisuutta, tasa-arvoisuutta ja suunnittelua elinikäisen kasvatuksen toteuttamiseksi.

\section{Nykyiset aikuis- koulutuspalvelut ja osallistumattomuus}

Nykyiset aikuiskoulutuksen opiskeluaiheet voidaan karkeasti jakaa seuraaviiłt pääryhmiin:

1) Yleissivistävän koulutuksen täydentämiseen tähtäävät opinnot

2) Ammatillinen aikuiskoulutus

3) Aikuisten korkeakouluopinnot

4) Harrastusopinnot

Palvelujen määrä ja koulutuksen alueellinen saavutettavuus on nykyään useimmilla alueilla hyvin järjestetty ja uusia kehittämisideoita saataneen lisää eri alojen toimikuntien jättäessä muistionsa.

Useissa osallistumista selvittävissä tutkimuksissa todetaan, että koulıtuspalvelujen lisääminen saattaa jopa lisätä koulutuksellista eriarvoisuutta, sillä aikuisopintoihin osallistuvat yleensä eniten ne, joilla on jo ennestään hyvä koulutuspohja. Tästä voidaan tietysti helposti syyttää aikuiskoulutusjärjestelmää ja kouluttajia, mutta on aina syytä muistaa, että puhuttaessa vuorovaikutussuhteesta se toimiakseen edellyttää kaikinpuolista yhteistyötä.

\section{Aikuiskasvatuksen ja yhteiskunnan vuoro- vaikutuksen kehittä- minen}

Jaostotyöskentelyssä tärkeimpinä vuorovaikutuksen lisäämistä vaativina kohteina pidettiin seuraavia kahta:

1) työyhteisö - aikuiskasvatus

2) koulujärjestelmä - aikuiskasvatus
Työyhteisön kohdalla merkittävimpiä kehittämiskohtia ovat joustavan työelämästä koulutukseen ja takaisin siirtymisen mahdollistaminen elintasoa vaarantamatta. Kuitenkin koulutukseen osallistumisen täytynee taata henkilölle myös konkreettisia edistymismahdollisuuksia joko omalla ammattialallaan tai muuten yhteiskunnan koulutukseen osallistumismotivaation parantamiseksi.

Koulujärjestelmän ja aikuiskasvatuksen vuorovaikutuksen kehittäminen edellyttää joustavuuden ja yhteistyön lisäämistä. Eräänä oleellisena lähtökohtana voisi olla vertailukelpoisten tutkintojärjestelmien luominen siten, että eri järjestelmissä suoritetut oppimäärät tai kurssit olisivat keskenään vertailukelpoisia. Lisäksi opiskelijan siirtymisen oppilaitoksesta tai koulumuodosta toiseen tulisi voida tapahtua joustavasti kunhan hänen opiskeluedellytyksensä ylemmässä oppilaitoksissa selvitetään lähtötasomittauksella ja tarvittaessa lisäkurssitukselia.

Vuorovaikutuksen kehittämistä suunniteltaessa on oleellisimpana lähtökohtana muistettava yksilö. Koulutusjärjestelmän on lähdettävä yksilön tarpeista ja elämäntilanteesta sekä hänen kokonaispersoonallisuutensa tasapainoisesta kehittämisestä. Näiden näkemysten siirtäminen lueteltujen fraasien tasolta käytännön toteutukseen edellyttää yhteistyöhalukkuutta ja tiettyä asenteiden muuttumista yhteiskunnan kaikilla tasoilla. Mielenkiintoista onkin jäädä odottamaan kuinka nopeasti jätettävien toimikuntatöiden esityksistä päästään päätösten ja käytännön toteutusten tasolle. 